\title{
Aquifer Unit Management Plan (AUMP) For Groundwater Resources Management of Multi-layered Coastal Aquifer System
}

Devadasan Gnanasundar ( $\sim$ dgsundar@yahoo.com )

Central Ground Water Board

Mohanavelu Senthilkumar

Central Ground Water Board

\section{Research}

Keywords: Coastal aquifer, multi-layered, groundwater, management, pumping, seawater intrusion

Posted Date: September 2nd, 2021

DOI: https://doi.org/10.21203/rs.3.rs-779228/v1

License: (ㄷ) (i) This work is licensed under a Creative Commons Attribution 4.0 International License. Read Full License 


\section{Abstract}

To address the vulnerability of coastal aquifer to over exploitation and sea water intrusion, a groundwater resources management plan titled as Aquifer Unit Management Plan (AUMP) is designed to provide valuable guidance for groundwater management of a multi-layered cuddalore coastal aquifer system located east coast of South India. The aquifer unit management plan is based on the summative examination of the aquifer unit disposition, response of hydraulic heads to recharge and discharge and effect of increased pumping on aquifer hydraulics. The safe hydraulic heads and annual exploitable potential were considered as the guiding factors to manage fresh groundwater resources of the coastal aquifer. The results show that the process of sea water intrusion has already started and with the present rate of pumping (1034.86 mcmy $\left.{ }^{-1}\right)$, the sea water intrusion risk has increased manifold all along the coast. The salient management strategies recommended are; restricting pumping to 695 mcmy $^{-1}$, stepping up recharge activities in recharge zone, adopting water use efficiency methods and regulation in the coastal zone. AUMP is simple and can guide water managers to plan for sustainable groundwater withdrawal and safe guard the coastal aquifer from sea water intrusion and ensure sustainability of groundwater abstraction structures.

\section{Introduction}

The management of multilayered coastal aquifers are challenging due to its vulnerability to sea water intrusion along the coastal zone. The fragility of the multilayered coastal aquifers and their sensitivity to excessive groundwater withdrawal (Hoori 2020) demands a comprehensive aquifer management plan for holistic understanding of the coastal aquifer system and management of its precious groundwater resources in a sustainable manner(Aristotelis2003, Manivannan and Elango 2019). Studies on groundwater management in coastal aquifers have been carried out by various researchers (Cendrero and Fischer1997; Gnanasundar and Elango 2000; Reichard and Johnson 2005;Siakaet al 2017). Flow in coastal aquifers is very complex processes (Bear 1999) but management plans that identifies issues and provide less complex strategies to protect fresh groundwater resources is necessary. Due to muddled groundwater development and in absence of groundwater management plan, a multi-layered coastal aquifer (called as Cuddalore Coastal Aquifer System - CCAS) located at east coast of South India is vulnerable to over exploitation and faces threat of sea water intrusion. In lieu of the above, the authors had conceived a management plan named as Aquifer Unit Management Pan (AUMP) that can provide valuable guidance for groundwater management of multi-layered CCAS.

\section{Description Of Study Area And Location}

The Cuddalore coastal aquifer system is one of the most prolific coastal aquifer located 200 North of Chennai, India lying between the latitudes $11^{\circ} 30^{\prime}$ to $11^{\circ} 55^{\prime}$ and longitudes $79^{\circ} 15^{\prime}$ to $79^{\circ} 50^{\prime}$ and covering an area of $2100 \mathrm{Km}^{2}$. The length (N-S) of the aquifer is $32 \mathrm{kilometer}$ and width (W-E) is 58 kilometer approximately. The northern boundary is defined by up dip along the Ponnaiyar River and the southern boundary by Vellar River (Fig. 1). The archeans (Biotite Hornblende Gneiss forms the western boundary and Bay of Bengal Sea constitutes the eastern boundary.Along the west, sandstones crop out and underlie towards the east coast and dip gently eastward beneath the Bay of Bengal. The topographic elevation is at $120 \mathrm{~m}$ mean sea level $(\mathrm{msl})$ in the west and gradually slopes towards east where at coast the elevation is at msl. The mean annual precipitation for the years 1999 to 2018 is $1290 \mathrm{~mm}$. This region is intensively irrigated by groundwater with dominant land use consists of cultivated crops (almost 80 \% of the area) such as rice, sugarcane, groundnut, banana, cashew, millets and vegetables. Cuddalore and Neyveli and are the prominent towns and Asia's largest open cast lignite mine (Neyveli lignite mine) is operational within the study area since 1956.

\section{Materials And Methods}

The Aquifer Unit Management Plan (AUMP) constitutes 7 steps, the description;salient outcome of each step is given as Table 1. An aquifer system constitutes one or many major aquifers and several aquifer units within (CGWB, 2017). For management of coastal aquifers, the dispositions of the aquifer units are to be explored and its hydraulic characteristics are to be assessed. The exploratory drilling data (78 nos), geophysical resistivity logging data (36 nos) generated from the aquifer mapping study of Central Ground Water Board (CGWB) were used to decipher hydrostratigraphic units, delineate major aquifers/aquifer units and develop conceptual model. The hydraulic head data (57 nos) used in the study for analyses are from the groundwater monitoring program of Central Ground Water Board(CGWB 2020). The practical knowledge gained by the authors during field hydrogeological studies between 2011 and 2014 were applied to arrive at logical assumption wherever necessary. 
Table 1

Steps or Methodology of the Aquifer Unit Management Plan (AUMP)

\begin{tabular}{|c|c|c|}
\hline Steps & Description & Salient outcome \\
\hline I & $\begin{array}{l}\text { Decipher/establish } \\
\text { the aquifer units }\end{array}$ & $\begin{array}{l}\text { The hydrostratigraphic units, major aquifers and aquifer units within the aquifer system are deciphered and } \\
\text { named. }\end{array}$ \\
\hline II & $\begin{array}{l}\text { Develop conceptual } \\
\text { model }\end{array}$ & $\begin{array}{l}\text { The basinal, hydraulic features of the aquifer units are figured out and conceptual model of aquifer system is } \\
\text { developed. }\end{array}$ \\
\hline III & $\begin{array}{l}\text { Assess recharge to } \\
\text { the aquifer units }\end{array}$ & The pumping history, groundwater withdrawal for irrigation, industry and drinking water sectors are estimated. \\
\hline IV & $\begin{array}{l}\text { Assess discharge } \\
\text { from the aquifer } \\
\text { units }\end{array}$ & $\begin{array}{l}\text { The recharge zones, rate of rainfall recharge, source of recharge and artificial recharge to the aquifer units are } \\
\text { estimated. }\end{array}$ \\
\hline \multirow[t]{2}{*}{ V } & $\begin{array}{l}\text { Status of the aquifer } \\
\text { units }\end{array}$ & $\begin{array}{l}\text { The response of the hydraulic heads (annual and long term) to hydraulic stress, comparison of current hydraulic } \\
\text { head elevation with historic head elevation. }\end{array}$ \\
\hline & & Projection of the scenario from long term pumping rate, hydrograph and numerical modelling. \\
\hline $\mathrm{VI}$ & $\begin{array}{l}\text { Sensitizing public on } \\
\text { status of the aquifer } \\
\text { units }\end{array}$ & $\begin{array}{l}\text { Sensitizing farmers and people on user aquifer units and appraise issue on decline in hydraulic heads and } \\
\text { issues that threatens the sustainability of dug wells and tube wells. }\end{array}$ \\
\hline VII & $\begin{array}{l}\text { Aquifer } \\
\text { management } \\
\text { strategies }\end{array}$ & $\begin{array}{l}\text { Governing aquifer hydraulic principles, comprehensive aquifer unit management plan that includes pumping } \\
\text { limit, safe hydraulic heads, and management measures to be taken in stressed aquifer unit's including } \\
\text { administrative measures. }\end{array}$ \\
\hline
\end{tabular}

\section{Results And Discussion}

\subsection{Step I Decipher/establish the aquifer units}

Table 2. Stratigraphic correlations between Geologic, Hydrostratigraphic units and aquifer units of CCAS. 
Table 2

Stratigraphic correlations between Geologic, Hydrostratigraphic units and aquifer units of CCAS.

\begin{tabular}{|c|c|c|c|c|c|c|c|c|}
\hline \multirow[t]{2}{*}{ Era } & \multirow[t]{2}{*}{ Period } & \multirow{2}{*}{\multicolumn{2}{|c|}{ Series/Epoch }} & Geologic & \multirow{2}{*}{$\begin{array}{l}\text { Hydrostratigraphic } \\
\text { Unit (detailed) }\end{array}$} & \multirow{2}{*}{$\begin{array}{l}\text { Major } \\
\text { Aquifer }\end{array}$} & \multirow[t]{2}{*}{ Aquifer Units } & \\
\hline & & & & Unit/Formation & & & & \\
\hline \multirow[t]{12}{*}{ Cenozoic } & Quaternary & \multicolumn{2}{|c|}{ Holocene/Pleistocene } & Alluvium sand & \multirow{2}{*}{$\begin{array}{l}\text { Upper Cuddalore } \\
\text { Aquifer }\end{array}$} & \multirow{4}{*}{$\begin{array}{l}\text { Cuddalore } \\
\text { Aquifer }\end{array}$} & \multirow{2}{*}{$\begin{array}{l}\text { Unconfined } \\
\text { Aquifer Zone } \\
\text { (Aquifer Unit } \\
\text { - I) }\end{array}$} & \multirow{12}{*}{$\begin{array}{l}\text { Cuddalore Coastal } \\
\text { Aquifer System }\end{array}$} \\
\hline & \multirow[t]{11}{*}{ Tertiary } & \multirow[t]{3}{*}{$\begin{array}{l}\text { Mio- } \\
\text { Pliocene }\end{array}$} & late & \multirow{3}{*}{$\begin{array}{l}\text { Cuddalore } \\
\text { Formation } \\
\text { (Cuddalore } \\
\text { sandstones) }\end{array}$} & & & & \\
\hline & & & early & & \multirow[t]{2}{*}{$\begin{array}{l}\text { Lower Cuddalore } \\
\text { Aquifer }\end{array}$} & & $\begin{array}{l}\text { Confined } \\
\text { Aquifer Zone }\end{array}$ & \\
\hline & & & & & & & $\begin{array}{l}\text { (Aquifer Unit } \\
- \text { II) }\end{array}$ & \\
\hline & & \multicolumn{6}{|c|}{ Unconformity } & \\
\hline & & \multirow[t]{7}{*}{ Eocene } & late & \multirow{7}{*}{$\begin{array}{l}\text { Neyveli } \\
\text { Formation } \\
\text { (Neyveli } \\
\text { sandstones) }\end{array}$} & \multirow[t]{2}{*}{$\begin{array}{l}\text { Upper Neyveli } \\
\text { Aquifer }\end{array}$} & \multirow[t]{7}{*}{$\begin{array}{l}\text { Neyveli } \\
\text { Aquifer }\end{array}$} & $\begin{array}{l}\text { Confining } \\
\text { Aquifer Zone }\end{array}$ & \\
\hline & & & & & & & $\begin{array}{l}\text { (Aquifer Unit } \\
\text { - III) }\end{array}$ & \\
\hline & & & middle & & \multirow[t]{2}{*}{$\begin{array}{l}\text { Middle Neyveli } \\
\text { Aquifer }\end{array}$} & & $\begin{array}{l}\text { Confining } \\
\text { Aquifer Zone }\end{array}$ & \\
\hline & & & & & & & $\begin{array}{l}\text { (Aquifer Unit } \\
- \text { IV) }\end{array}$ & \\
\hline & & & \multirow[t]{3}{*}{ early } & & \multirow[t]{3}{*}{$\begin{array}{l}\text { Lower Neyveli } \\
\text { Aquifer }\end{array}$} & & $\begin{array}{l}\text { Confining } \\
\text { Aquifer Zone }\end{array}$ & \\
\hline & & & & & & & $\begin{array}{l}\text { Aquifer Unit } \\
-V\end{array}$ & \\
\hline & & & & & & & $\begin{array}{l}\text { (exists } \\
\text { beyond } 400 \\
\text { mbgl) }\end{array}$ & \\
\hline \multicolumn{9}{|c|}{ Unconformity } \\
\hline \multirow[t]{2}{*}{ Mesozoic } & \multirow[t]{2}{*}{ Cretaceous } & \multirow{2}{*}{\multicolumn{2}{|c|}{ Late }} & \multirow{2}{*}{$\begin{array}{l}\text { Puvanur } \\
\text { Formation }\end{array}$} & \multicolumn{3}{|c|}{ Fossiliferrous siliceous Limestone } & \\
\hline & & & & & \multicolumn{3}{|c|}{ Calcareous sandstone and marls } & \\
\hline \multicolumn{9}{|c|}{ Unconformity } \\
\hline Proterozoic & Archaean & Intrusives & & $\begin{array}{l}\text { Granitoid } \\
\text { Gneiss }\end{array}$ & Basement & & & \\
\hline
\end{tabular}

The CCAS has a layered sequence of aquifers composed of sandstones that thicken and deepen to the east towards the Bay of Bengal Sea. The basement exposed in the western part has not been encountered in the eastern and southwestern part due to thickening of the tertiary sedimentary sequence from west to east (Subramanyam 1969). The hydro-stratigraphic units and aquifer units were deciphered by the authors after analysis of borehole lithology, geophysical electrical logs and from previous studies (Paul and Subramanyam 1961, Subramanyam 1969, Mandaokar and Debi 2014, Elayarajaa and Kumarasamy 2019,)to establish coherence between the geologic period, series/epoch, geologic unit/formation, hydrostratigraphic unit and aquifer units (Table2). The CCAS constitutes two major aquifers (Cuddalore and Neyveli aquifers) and five aquifer units (Aquifer Unit I, II, III, IV and V) down to the depth of $400 \mathrm{~m}$ below ground level (bgl). The aquifer units exist throughout the CCAS and pinches in northwestern and western boundaries. Lignite seam of 10 to 22 meters coexists along with a discontinuous clay layer of 3 to $7 \mathrm{~m}$ between the Cuddalore and Neyveliaqufiers. The Cuddalore aquifer comprises of argillaceous sandstone, pebble bearing sandstone, ferruginous arkosicssandstone, gravel, grits and clay beds. They are friable, whitish, pinkish, and reddish in color deposited under continental, fluvial and nearbvshoreenvironment. The Neyveli aquifer comprises of friable calcareous sandstones, lignite seam, sandy limestones, clay and carbonaceous clay. They are more compact than the Cuddalore aquifer and are deposited influvio-marine, paralic, deltaic, near shore to inner shelf environment (Selvarajand Ramasamy 1998).

\subsection{Step II Develop Conceptual model}

The sandstones of CCAS have strike along NNE to SSW direction with a dip of 20》 to 25区 towards ESE or SE direction. Clay as intercalations occur with the within sandstones and is predominant near the coast (Paul andSubramanyam 1961). The clay layer (aquitard) occurring at top and bottom of the sandstones hydraulically separates the aquifer units. The varying hydraulic head elevations(Fig. 2) substantiate that the aquifer units function as multi-layered aquifer system (Anandan et al 2009, CGWB 2015). The vertical leakance (upward or downward flow) exists among the aquifer units where clay is minimal or absent. The hydraulic conductivity $(K)$ ranges from 18 to $115 \mathrm{~m} /$ day. The degree in sorting, cementing and compaction 
accounts for varying permeability among the units. The tube wells tapping these units have yield varying between $18 \mathrm{~m}^{3} \mathrm{~h}^{-1}$ and $220 \mathrm{~m}^{3} \mathrm{~h}^{-}$

${ }^{1}$ sustaining for 10 to 12 hours of pumping with 3 to $5 \mathrm{~m}$ drawdown. The groundwater flow is from northwest to southeast direction, pre-dominantly horizontal and finally seeps into Bay of Bengal Sea. In region around Neyveli lignite mine, the regional groundwater flow is distorted. Fresh groundwater water discharge through sea bottom occurs asCCASis a part of Cauvery basin extends into the sea for several kilometers (Nagendra and Nallapa A 2017, Twinkle et al 2016). The conceptual model of CCAS is given as Fig. 3.

\subsubsection{Aquifer Unit I}

The Aquifer Unit I is the top most aquifer unit composed of sandstones of late mio-pliocene age, alluvium and Laterite formations. The alluvium formation (sand and sandy clay) overlies the sandstones towards east. Clay as intercalations occurs within the alluvium sand and its thickness increases towards coast as well as towards south west of Vellar River. The thickness of this aquifer unit I is 30 to $110 \mathrm{~m}$. The groundwater in aquifer unit I is fresh and occur under unconfined conditions. Groundwater development is by dug wells and few dug cum-tube wells. The dug wells have diameter of 1 to $3 \mathrm{~m}$ and are lined by bricks or perforated concrete concentric rings. The depth of the dug wells ranges from 3 to $35 \mathrm{~m}$ bgl and their water level ranges between 1.5 and $26 \mathrm{~m}$ bgl. Perched water table occurs at 3 to $10 \mathrm{~m}$ bgl formed by the presence of thick clay in the central region. The Electrical conductivity (EC) of the groundwater ranged between 350 and $1500 \mu \mathrm{S} / \mathrm{cm}$. Rainfall is the major source of aquifer replenishment. Apart from rainfall, groundwater recharge also occurs from irrigation return flow, ponds/tanks and by recharge through artificial recharge structures. The yield of the aquifer unit varied between 10 and $65 \mathrm{~m}^{3} \mathrm{~h}-1$. The transmissivity $(\mathrm{T})$ of the aquifer I ranged between 450 and $940 \mathrm{~m}^{2} / \mathrm{day}(\mathrm{Paul}$ and Subramanyam 1961) and the specific yield (Sy) ranges between 9 to $17 \%$.

\subsubsection{Aquifer Unit II}

The aquifer unit - II lies below the Aquifer unit I and is composed of sandstones of early Mio-Pliocene age. The top of the aquifer - II lies at 10 to 120 $\mathrm{m}$ bgl. The thickness of the Aquifer Unit II varies from 30 to $55 \mathrm{~m}$. The groundwater abstraction from the aquifer is by tube wells ranging from 40 to $100 \mathrm{~m}$ bgl. Groundwater occurs under confined conditions with the hydraulic head of the aquifer II ranging between 14 and $-24 \mathrm{~m} \mathrm{msl}$. Apart from rainfall, groundwater recharge occurs from vertical leakage from aquifer I. The yield of the aquifer unit varied between 43 and $102 \mathrm{~m}^{3} \mathrm{~h}^{-1}$. The EC of the aquifer ranged between 450 and $1200 \mu \mathrm{S} / \mathrm{cm}$. The transmissivity(T) of the aquifer II range between 780 and $1980 \mathrm{~m}^{2} /$ day and the storativity (S) ranges between $1.2 \times 10^{-3}$ to $4.1 \times 10^{-4}$ (Paul and Subramanyam 1961).

\subsubsection{Aquifer Unit III}

The aquifer unit - III underlies the Aquifer unit II and is composed of sandstones of late Eocene age. Lignite (Brown Coal) occurs on top of the sandstones and is considered as marker bed. Lignite seams also occur within the sandstones at depths. Clay as intercalations occurs within the sandstones lignite seams. The top of the Aquifer unit III lies at 90 to $160 \mathrm{~m}$ bgl. The thickness of the Aquifer Unit III varies from 30 to $100 \mathrm{~m}$. The groundwater in the aquifer unit III occurs under confined conditions with the hydraulic head ranging between 7.0 and $-28.5 \mathrm{~m}$ msl. The yield varies from 72 and $170 \mathrm{~m}^{3} \mathrm{~h}^{-1}$. The EC of the groundwater ranged between 300 and $1000 \mu \mathrm{S} / \mathrm{cm}$. The T of the aquifer III range between 670 and $2100 \mathrm{~m}^{2} / \mathrm{day}$ and the $S$ ranged between $1.6 \times 10^{-4}$ and $2.9 \times 10^{-5}$ (Paul and Subramanyam 1961).

\subsubsection{Aquifer Unit IV}

The aquifer unit IV constitutes middle Eocene sandstone and lies below the Aquifer III. The top of the Aquifer IV lies at 50 to $280 \mathrm{~m}$ bgl. The aquifer unit IV is thicker than the other units and extends beyond 400 mbglnear the coast. The thickness varies from 50 to $130 \mathrm{~m}$. The groundwater occurs under confined conditions with the hydraulic head ranging between 9.0 to $-30.5 \mathrm{~m} \mathrm{msl}$. The aquifer IV is highly potential aquifer and its yield variesfrom64 to $158 \mathrm{~m}^{3} \mathrm{~h}^{-1}$. The EC ranged between 500 and $1300 \mu \mathrm{S} / \mathrm{cm}$. The T of the aquifer IV range between 980 and $2700 \mathrm{~m}^{2} / \mathrm{day}$ and the S ranges between $4.3 \times 10^{-4}$ to $9.1 \times 10^{-5}$ (Paul and Subramanyam 1961).

\subsubsection{Step IIIAssess Recharge to Aquifer Units}

The recharge to the CCAS occurs through a) infiltration of rainfall on the outcrop in the western margin covering an area of $220 \mathrm{~km}^{2}$ (Anandan et al 2010). b) an area covering $350 \mathrm{~km}^{2}$ between Ponnaiyar and GadilamRiver) area of $110 \mathrm{~km}^{2}$ between Manimuktar and Vellar river d) subsurface inflow across north western boundary d) return flow from irrigation activity and e) seepage from the tanks, ponds and artificial recharge structures. Approximately 58 percent of total rainfall $(1290 \mathrm{~mm})$ is by the north-east monsoon (October, November, December and January) and 30 percent of rainfall is contributed by the south-west monsoon (July, August and September). Rainfall occurs almost in every month of a year and the rainy day accounts for 45 to 63 days in a year. The month March to May has the minimum number of rainy days in any year and the period October to January has the maximum number of rainy days. Rangarajan et al 2005 in their study concluded high recharge rate of 24 to 40 percent of rainfall occurs along the western part of the region covering an area of $650 \mathrm{~km}^{2}$. In the remaining region, rainfall accounts to 8 to $16 \%$ of the annual recharge (CGWB, 2015). The estimated recharge rate is $772 \mathrm{mcm} \mathrm{y}^{-1}$ for $1290 \mathrm{~mm}$ of rainfall. The natural recharge occurs in all the four aquifer units during monsoon, but recharge to aquifer unit I is comparatively high than the other aquifer units as72 percent of its formation is exposed to the ground surface.

\subsubsection{Step IV Assess discharge from the aquifer units}

Page 5/14 
The groundwater withdrawal from the aquifer units prescribes the aquifer unit management plan. The discharge from Cuddalore coastal aquifer system occurs as (a) withdrawals by irrigation, industrial, mining activity (depressurization) (b) public supply wells and c) free flowing wells (artesian condition). Before 1960, discharge was mainly by pumping from about 145 flowing wells to the south of Cuddalore, apart from the underflow towards Gadilam and Vellar rivers (Paul and Subramanyam 1961). The energisation of the dug wells during early 1970 's led to increase in groundwater withdrawal for irrigation (Fig. 4). The total annual groundwater withdrawal during early 80's was estimated at 350 to 400 million cubic meters (mcm). Presently (2019) the estimated annual withdrawal by pumping is estimated at $1034.86 \mathrm{mcm}$ (Table 3 ). About $84 \%$ of groundwater withdrawals are from aquifer unit I and II of which irrigation accounts to $97 \%$. The large scale groundwater pumping or depressurization activity in aquifer unit III for safe mining of lignite deposits commenced during 1961 and is confined in and around Neyveli lignite mines (Anandan et al 2009, 2010).Presently about $133.10 \mathrm{mcm}$ of groundwater is pumped annually. The Metro-water of state department withdraws $12.79 \mathrm{mcm}$ of groundwater annually from Aquifer unit IV during lean periods (April to July). The groundwater pumped is transported $200 \mathrm{~km}$ through pipelines to cater drinking water supply of Chennai city.

\subsubsection{Step V Status of the aquifer units}

The status of the aquifer units reflects the hydraulic functioning of the coastal aquifer wherein the response of the hydraulic heads to stress (recharge and pumping) and its vulnerability to over exploitation and sea water intrusion is brought out. The sensitivity and magnitude of the stress abide within the aquifer units need to be figured out to impute corrective measures in the management plan. The change (lowering) in the hydraulic heads of the aquifer units in the recharge (western), intermediate (Central) and coastal zone (eastern) portray the impact of heavy pumping and vulnerability to seawater intrusion. The magnitude of the aquifer stress is difference between the annual discharges by pumping with annual recharge. Considering natural recharge and groundwater discharge by pumping, the groundwater budget was negative by late 1980 . Currently the total recharge is $\sim 26$ percent less than the estimated total extraction which is alarming and this percent difference is likely to increase in the coming years. For convenient sake, the western and central region together is denoted as Inland zone. In the central and eastern region, the hydraulic heads of the aquifer unit I almost remain the same or decline is insignificant with the average hydraulic head fluctuation (annual rise and fall) of 4 to $9 \mathrm{~m}$. (Fig. 5 ). However, the western region is de-saturated by $45 \mathrm{~m}$ due to decline in hydraulic heads. The hydraulic heads of aquifer unit II in the western margin lowered from positive hydraulic pressure head $(+60$ to $+80 \mathrm{~m})$ to negative hydraulic pressure head $(-24 \mathrm{~m} \mathrm{msl})$. Similarly, the hydraulic heads of aquifer unit III and IV lowered from positive hydraulic pressure head $(+60$ and $+80 \mathrm{~m})$ to negative hydraulic pressure head $(-28.5 \mathrm{and}-30.5 \mathrm{~m} \mathrm{msl})$ respectively. The cumulative long term negative imbalance between recharge and discharge (discharge $>$ recharge) has lowered the hydraulic head in the aquifer units. The historic hydraulic heads of aquifer units II, III and IV in the central and eastern region were above mean sea levels and the tube wells tapping these aquifers were under artesian conditions(Paul and Subramanyam 1961) and artesian conditions existed until mid-1980 (CGWB, 2015 ). The present status and the hydraulic features of CCAS is given as Table 4.

Table 3 Groundwater withdrawal (Year: 2019) from the aquifer units for domestic, agricultural and Industrial activities

\begin{tabular}{|c|c|c|c|c|}
\hline Formation & Aquifer Units & Irrigation & $\begin{array}{l}\text { Industrial } \\
(\mathrm{mcm} / \text { year })\end{array}$ & Domestic/Drinking \\
\hline Sand/sandstone & Aquifer I & 315.0 & 0.8 & 29.50 \\
\hline Sandstone & Aquifer II & 517.32 & 1.2 & \\
\hline Sandstone & Aquifer III & 25.15 & 133.10 & \\
\hline Sandstone & Aquifer IV & & & 12.79 \\
\hline Sandstone & Aquifer $\mathrm{V}$ & \multicolumn{3}{|c|}{ (no groundwater withdrawal) } \\
\hline Total ( $\mathrm{mcm} /$ year) & & 857.47 & 135.10 & 42.29 \\
\hline
\end{tabular}


Table 4

Hydraulic features and status of the aquifer units

\begin{tabular}{|c|c|c|c|c|}
\hline Parameters & $\begin{array}{l}\text { Aquifer unit I } \\
\text { (unconfined) }\end{array}$ & $\begin{array}{l}\text { Aquifer Unit II } \\
\text { (Confined) }\end{array}$ & $\begin{array}{l}\text { Aquifer Unit III } \\
\text { (Confined) }\end{array}$ & $\begin{array}{l}\text { Aquifer Unit IV } \\
\text { (Confined) }\end{array}$ \\
\hline Usage & Domestic/drinking and Irrigation & $\begin{array}{l}\text { Irrigation and } \\
\text { Industrial }\end{array}$ & Mining activity and irrigation & $\begin{array}{l}\text { Drinking water } \\
\text { supply }\end{array}$ \\
\hline \multirow{2}{*}{$\begin{array}{l}\text { Hydraulic } \\
\text { head } \\
\text { (pre- } \\
\text { development) }\end{array}$} & \multirow[t]{2}{*}{ Above msl } & Auto-flowing & Auto-flowing & Auto-flowing \\
\hline & & Up to late 80 's & Up to early90's & Up to early 90 's \\
\hline $\begin{array}{l}\text { Hydraulic } \\
\text { Head (pre- } \\
\text { monsoon } \\
2019 \text { ) }\end{array}$ & 1.5 to 26 & 14.0 to -24.0 & 7.0 to -28.5 & 9.0 to -30.5 \\
\hline \multicolumn{5}{|l|}{$\begin{array}{l}\text { inland (m } \\
\mathrm{msl})\end{array}$} \\
\hline $\begin{array}{l}\text { Hydraulic } \\
\text { Head (pre- } \\
\text { monsoon } \\
\text { 2019) }\end{array}$ & 0.5 to 1.5 & -2.0 to -7.0 & $\mathrm{msl}$ to -3.0 & $\mathrm{msl}$ to -2.0 \\
\hline \multicolumn{5}{|l|}{$\begin{array}{l}\text { Coastal zone } \\
(\mathrm{m} \mathrm{msl})\end{array}$} \\
\hline $\begin{array}{l}\text { Long term } \\
\text { Decline in } \\
\text { Hydraulic } \\
\text { head } \\
\text { (meter per } \\
\text { year) }\end{array}$ & $\begin{array}{l}\text { No decline in the central and } \\
\text { coastal zone but decline in the } \\
\text { western margin }\end{array}$ & 0.20 to 0.30 & 0.10 to 0.30 & 0.10 to 0.20 \\
\hline $\begin{array}{l}\text { Impact of } \\
\text { pumping } \\
\text { since } 1970\end{array}$ & $\begin{array}{l}\text { De-saturated in western and } \\
\text { central region by } 45 \mathrm{~m}\end{array}$ & $\begin{array}{l}\text { Drop in } \\
\text { hydraulic head }\end{array}$ & $\begin{array}{l}\text { Drop in hydraulic head and Cone of depression } \\
\text { around Lignite mine. Upward vertical leakage in } \\
\text { places where clay is absent }\end{array}$ & $\begin{array}{l}\text { Drop in hydraulic } \\
\text { head }\end{array}$ \\
\hline & & $\begin{array}{l}\text { Sea water } \\
\text { intrusion near } \\
\text { Cuddalore } \\
\text { town }\end{array}$ & & $\begin{array}{l}\text { Upward vertical } \\
\text { leakage in places } \\
\text { where clay is absent }\end{array}$ \\
\hline \multirow[t]{2}{*}{ Status } & \multirow{2}{*}{$\begin{array}{l}\text { Threat of sea water intrusion if } \\
\text { hydraulic head lowers below msl } \\
\text { in the coastal zone. }\end{array}$} & \multirow{2}{*}{\multicolumn{3}{|c|}{$\begin{array}{l}\text { Threat of sea water intrusion if hydraulic head lowers } \\
\text { below }-3 \mathrm{~m} \text { in the coastal zone }\end{array}$}} \\
\hline & & & & \\
\hline $\begin{array}{l}\text { Threat of sea } \\
\text { water } \\
\text { intrusion }\end{array}$ & \multicolumn{4}{|c|}{ Coastal zone vulnerable to sea water intrusion from coast to $10 \mathrm{~km}$ inland. } \\
\hline
\end{tabular}

Figure 5 Long term (Period: 1973-2018) hydraulic head fluctuation and trend of aquifer unit I.

Table 4 Hydraulic features and status of the aquifer units

Continuous and heavy withdrawal of groundwater $\left(\sim 865 \mathrm{mcmy}^{-1}\right)$ for irrigation in the last 2 decades induced decline in hydraulic heads (western and central region) of the aquifer unit II at the rate averaging 0.20 meter per year. The hydraulic heads of aquifer unit III and IV decline around lignite mines at $\sim 0.20 \mathrm{my}^{-1}$ for pumping that accounts for just $14 \%(\sim 170 \mathrm{mcm})$ of total pumping. The aquifer unit III with high hydraulic pressure infuses water into aquifer unit II by upward vertical leakage (Anandan2010) thereby losing water in its storage apart from annual discharge of 130 mcm by pumping.Similarly, the aquifer unit IV infuses water into aquifer unit III by upward vertical leakage from its storage apart from annual discharge of $12.79 \mathrm{mcm}$ by pumping. In the region within and around the lignite mine, the hydraulic heads continue to decline (Ravikumar et al 2010$)$ at 0.20 to $0.30 \mathrm{~m} /$ year. The average hydraulic fluctuations (annual rise and fall) of aquifer unit III and IV are less $(\sim 0.5 \mathrm{~m})$ than the above aquifer units ( 1 to $2.5 \mathrm{~m}$ ). These situations roughly provide us an understanding (hydraulic functioning) that recharge to deeper aquifer units (III and IV) could be less than $22 \%(\sim 170 \mathrm{mcm})$ of total annual recharge $(772 \mathrm{mcm})$.

The hydraulic continuity of CCAS with the salt water (Bay of Bengal Sea) poses constant threat to the freshwater resources and vulnerable to sea water intrusion in the coastal zone.The coastal zone functions as hydraulic barrier between the salt water wedge and fresh water wherein the hydraulic pressure is mounted over the years. The hydraulic heads at mean sea level reflects equilibrium condition and thus the fresh and salt water interface are left undisturbed (Woo-Dong, 2019).Numerical modeling of CCAS unveil the region between coast and $10 \mathrm{~km}$ inland is highly sensitive even to 5 percent increase in pumping and hydraulic head of the confined aquifer units at- 5 msl reverses the recharge velocity flow direction towards 
the coastal aquifer or inland which in ideal condition (hydraulic head at msl) should be pointing towards sea (CGWB, 2015).Thus, it is crucial to maintain hydraulic heads (hydraulic equilibrium) of each aquifer units at mean sea level as decrease in hydraulic pressure or negative hydraulic pressure (hydraulic disequilibrium) induced by pumping in any one of the aquifer units initiate reversal of hydraulic gradient. The change in hydraulic head dynamics (from positive hydraulic pressure to negative hydraulic pressure)facilitates the salt water wedge (Holland, 1998) to move inland. To maintain hydraulic equilibrium, equivalent freshwater head that represents the column of fresh groundwater is required to balance the hydraulic pressure at a particular depth and groundwater density (Costall, 2020). The present hydraulic heads of the aquifer units III and IV in the coastal zone ranged between -3 and -5 and $\mathrm{msl}$ to $-2 \mathrm{~m}$ respectively. Even though the hydraulic heads of the aquifer units (II, III and IV) exists above the aquifer unit (top layer), hydraulic heads below mean sea level has the potential to trigger salt water wedge to march into the coastal aquifer (Sherif and Vijay1990, Woo-Dong 2019). The simulated results of numerical modelling studies (CGWB 2019a) for scenarios with increased pumping showed the recharge flow velocities deflected towards inland in regions where the hydraulic heads of confined aquifer units (Aquifer II, III and IV) dropped below $3 \mathrm{~m} \mathrm{msl}$. It can be precisely concluded that the confining aquifer units of CCAS will be subjected to sea water intrusion if the hydraulic heads lowers below $-3 \mathrm{~m} \mathrm{msl}$. The low hydraulic head of $-7 \mathrm{~m} \mathrm{msl}$ (negative hydraulic pressure) in aquifer unit II (CGWB 2019a) along northeastern region (negative hydraulic pressure area with recharge flow velocities towards inland or landward) thus indicate the process of sea water intrusion has started. Despite disadvantageous hydraulic conditions the groundwater in the aquifer units are presently fresh with electrical conductivity (EC) ranging between 330 and $1250 \mu \mathrm{S} / \mathrm{cm}$ (CGWB 2019b) except at northeast corner (near Cuddalore town) where, EC is $7200 \mu \mathrm{S} / \mathrm{cm}$. By 2022 , the annual pumping (projected from the present rate of pumping) would be around $1090 \mathrm{mcm}$ and the hydraulic head would decline further in absence of intervention or management strategy. Thus, CCAS is at high risk of being intruded by seawater all along the coast in near future. Senthilkumar et al 2017 reported due to heavy and continuous pumping of similar type of coastal aquifer system (Chennai coastal aquifer system), sea water intrusion has occurred up to 9 to $16 \mathrm{~km}$ inland and pumping was discontinued as reclaiming the intruded zone is a daunting task.

\subsubsection{Step VI Sensitizing public on status of the aquifer units}

Aquifer management plan that involves change in pumping pattern, crop pattern can be successful only when such type of plan in discussed with public by water managers, local administrators through Public interaction programme (Jadeja et al 2015, Amrtha, 2016). About $94 \%$ of the pumping wells in the region are privately owned and thus it is relatable to earn the favor of public in adhering to management options designed for implementation by the local authorities. The method of public interaction programme primarily depends on urban/rural mass and socio-economic conditions of the region. The major thrust is to expose or share people on the present status of the aquifer units and the consequence of over exploitation of groundwater resources in near future. The sensitive information on aquifer units thus shared with public raises scope for effective implementation of management strategies so as to ensure sustainability of the groundwater abstraction structures and protect the coastal aquifer from the threat of sea water intrusion.

\subsubsection{Step VII Aquifer Management Strategies}

The hydraulic characteristics of the aquifer units, groundwater development between withdrawal and discharge, response of hydraulic head to recharge and pumping over a period of time and the consequence of increased pumping on existing users were the criteria considered for AUMP. Numerical modelling which takes into account of the above criteria has guided to develop aquifer management plan (Gnanasundar and Elango, 2000, Senthilkumar and Elango, 2004, Barazzuoli, 2008.The simulation model results (CGWB, 2015) of existing and proposed groundwater management schemes was used to establish the safe yield, sustainable groundwater exploitation quantity and a reasonable groundwater exploitation scheme for the future. (Table 5). The numerical modeling study carried out by Gnanasundar and Senthilkumar (CGWB 2019a) established that hydraulic heads between $\mathrm{ms}$ land $3 \mathrm{~m} \mathrm{msl}$ has the potential to overcome the hydraulic pressure exerted by salt water front and therefore hydraulic head above msl upto- $3 \mathrm{~m} \mathrm{msl}$ is considered as safe hydraulic heads. The efficacy of the Aquifer Unit Management Plan lies in the evaluation of natural and artificial

recharge to the aquifer units, pumping and present scenario of the hydraulic heads in comparison with the historical heads. AUMP for coastal aquifer is based on the following aquifer management principles a) Pressure-head component of hydraulic head to exceed the elevation-head component in the discharge zone or coastal zone and create artesian conditions of the confined and unconfined aquifer unit. b) Maintain hydraulic equilibrium of the aquifer units. 
Table 5

Aquifer management strategies for Cuddalore coastal aquifer system.

\begin{tabular}{|c|c|c|c|c|c|c|c|c|c|}
\hline \multirow{4}{*}{$\begin{array}{l}\text { Aquifer } \\
\text { Units }\end{array}$} & \multirow{4}{*}{$\begin{array}{l}\text { Safe } \\
\text { hydraulic } \\
\text { heads } \\
\text { (m msl) } \\
\text { In } \\
\text { coastal } \\
\text { zone }\end{array}$} & \multirow{4}{*}{$\begin{array}{l}\text { Present } \\
\text { Pumping } \\
\text { Year: } 2019 \\
\text { (1034.86 } \\
\text { mcm/year) }\end{array}$} & \multirow{4}{*}{$\begin{array}{l}\text { Pumping } \\
\text { limit } \\
(690 \\
\text { mcm/year) }\end{array}$} & \multicolumn{6}{|c|}{ Aquifer management strategies } \\
\hline & & & & \multicolumn{5}{|c|}{ Reduction in pumping } & \multirow{2}{*}{$\begin{array}{l}\text { Increase in } \\
\text { recharge } \\
\text { Artificial } \\
\text { recharge } \\
\text { activity }\end{array}$} \\
\hline & & & & \multicolumn{2}{|c|}{$\begin{array}{l}\text { Recommended } \\
\text { Optimum } \\
\text { pumping per well } \\
\left(\mathrm{m}^{3} / \text { day) }\right.\end{array}$} & \multirow[t]{2}{*}{$\begin{array}{l}\text { Recommended } \\
\text { usage }\end{array}$} & \multirow[t]{2}{*}{$\begin{array}{l}\text { Regulatory } \\
\text { Measures } \\
\text { in the } \\
\text { coastal } \\
\text { zone }\end{array}$} & \multirow[t]{2}{*}{$\begin{array}{l}\text { Change in } \\
\text { method of } \\
\text { Irrigation }\end{array}$} & \\
\hline & & & & $\begin{array}{l}\text { Inland } \\
\text { zone }\end{array}$ & $\begin{array}{l}\text { Coastal } \\
\text { zone }\end{array}$ & & & & \\
\hline $\begin{array}{l}\text { Aquifer I } \\
\text { (unconfined) }\end{array}$ & $\begin{array}{l}\text { above } \\
\text { msl }\end{array}$ & 345.30 & 200 & 80 & 45 & $\begin{array}{l}\text { Domestic, } \\
\text { drinking and } \\
\text { irrigation }\end{array}$ & \multirow{4}{*}{$\begin{array}{l}\text { Drinking } \\
\text { water } \\
\text { supply, } \\
\text { domestic } \\
\text { and } \\
\text { irrigation } \\
\text { wells } \\
\text { operational } \\
\text { only } \\
\text { in aquifer } \\
\text { unit I } \\
\text { Withdrawal } \\
\text { restricted } \\
\text { for existing } \\
\text { and new } \\
\text { industry. } \\
\text { Telemetric } \\
\text { water level } \\
\text { and quality } \\
\text { monitoring } \\
\text { with high } \\
\text { frequency. }\end{array}$} & \multirow{4}{*}{$\begin{array}{l}\text { Flooding } \\
\text { method for } \\
\text { paddy should } \\
\text { be changed to } \\
\text { System of } \\
\text { Rice } \\
\text { Intensification } \\
\text { method } \\
\text { Drip irrigation } \\
\text { and sprinkler } \\
\text { irrigation } \\
\text { Interaction } \\
\text { with Public } \\
\text { through } \\
\text { Public } \\
\text { Interaction } \\
\text { Programme. }\end{array}$} & \multirow{4}{*}{$\begin{array}{l}\text { Stepping up } \\
\text { of recharge } \\
\text { activity* in } \\
\text { the up dip } \\
\text { region or } \\
\text { recharge } \\
\text { zone. } \\
\text { Construction } \\
\text { of series of } \\
\text { check dam } \\
\text { in western } \\
\text { region } \\
\text { between } \\
\text { Ponnaiyar } \\
\text { and } \\
\text { Gadilam } \\
\text { River \& } \\
\text { Manimuktar } \\
\text { and Vellar } \\
\text { River } \\
\text { *Percolation } \\
\text { ponds with } \\
\text { recharge } \\
\text { shaft are the } \\
\text { most } \\
\text { effective } \\
\text { artificial } \\
\text { recharge } \\
\text { structure. }\end{array}$} \\
\hline $\begin{array}{l}\text { Aquifer II } \\
\text { (Confined) }\end{array}$ & $\begin{array}{l}\text { Above } \\
\text { msl to }-3\end{array}$ & 518.52 & 320 & 80 & 45 & $\begin{array}{l}\text { Domestic, } \\
\text { drinking and } \\
\text { irrigation }\end{array}$ & & & \\
\hline $\begin{array}{l}\text { Aquifer III } \\
\text { (confined) }\end{array}$ & $\begin{array}{l}\text { Above } \\
\text { msl to }-3\end{array}$ & 158.25 & 150 & 120 & $\begin{array}{l}\text { No } \\
\text { pumping }\end{array}$ & $\begin{array}{l}\text { Depressurization } \\
\text { for safe mining } \\
\text { of lignite }\end{array}$ & & & \\
\hline $\begin{array}{l}\text { Aquifer IV } \\
\text { (Confined) }\end{array}$ & $\begin{array}{l}\text { Above } \\
\text { msl to }-3\end{array}$ & 12.79 & 20 & 120 & $\begin{array}{l}\text { No } \\
\text { pumping }\end{array}$ & $\begin{array}{l}\text { Drinking water } \\
\text { supply in the } \\
\text { event of drought } \\
\text { to Chennai city } \\
\text { and region } \\
\text { nearby. }\end{array}$ & & & \\
\hline
\end{tabular}

Table 5 Aquifer management strategies for Cuddalore coastal aquifer system.

Pressure-head component of the hydraulic head in the discharge zone or coastal zone can be enhanced by stepping up of recharge activity in the up dip region and recharge zone (western region). The solution to arrest lowering and further raise the hydraulic heads in the coastal zone lies in recharging the recharge zone as confined aquifer units are technically less feasible to be recharged even by injection wells in the coastal zone. Percolation pond with recharge shaft/recharge well and check dam are the effective artificial recharge structures in the up-dip and recharge zone as sand and gravel with high hydraulic conductivity ( $K=40$ to $115 \mathrm{~m} /$ day) facilitates high recharge (Marrykutty and Mohan 2019). In all possibility, it estimated that roughly 85 to $100 \mathrm{mcm}$ of water could be additionally recharged annually and this has the potential to increase the hydraulic pressure of confined aquifer units (Aquifer unit II, III and IV) in the coastal zone.

Maintaining hydraulic equilibrium of the aquifer units can be achieved by minimizing the percent difference between recharge and discharge (presently $31 \%$ ) and operating the aquifer system wherein the present hydraulic heads equals the safe hydraulic head. This is achievable by reducing pumping in a way to match the estimated permissible yield. The permissible yield (Koch 2012) is the annual exploitation potential ( $\left.E_{p r}\right)$ of the aquifer based on recharge or the total pumping rate that guarantees the average hydraulic head in each aquifer unit does not fall below safe hydraulic head (a vertical distance of -3meters from the mean sea level in the next 10 years). The annual exploitation potential (Er) of the aquifer based on recharge to the aquifer in $\mathrm{m}^{3}$ / area is calculated using the following formula:

$E_{p r}=A^{\star} R * D$ eq... 1

Where, $A=$ the area over which recharge to the aquifer take place $\left(\mathrm{m}^{2}\right) \mathrm{R}=$ rainfall recharge to the aquifer $(\mathrm{m} / \mathrm{a}) \mathrm{D}=\mathrm{abstractable}$ proportion of rainfall recharge. Approximately $10 \%$ of annual rainfall recharge is assumed to discharge from the coastal aquifer system as base flow/seepage to sea. $D$ is computed as follows;

$D=90 \%$ of Recharge $(R)$ eq....2 
As per Eqs. (1) and (2) the annual exploitation potential $\left(E_{\mathrm{pr}}\right)$ of an aquifer is computed as $695 \mathrm{mcm} \mathrm{y}^{-1}$. Thus the permissible yield of the entire CCAS should be lesser than $695 \mathrm{mcmy}^{-1}$.

Limiting annual groundwater withdrawal at $\sim 200 \mathrm{mcmagainst} 345.30 \mathrm{mcm}$ in aquifer unit I and $\sim 320 \mathrm{mcmagainst} 518.52 \mathrm{mcm}$ in aquifer unit II is the way forward and operate the aquifer system with total pumping not exceeding the annual exploitation potential $\left(695 \mathrm{mcmy}^{-1}\right)$. This can be partially achieved by stepping up recharge activities ( $100 \mathrm{mcm} /$ year $)$ as discussed earlier and by switching over to water use efficiency methods (Sudhir et al. 2013) like the System of Rice Intensification (SRI) method (Verma 2017) instead of flooding method for paddy, drip and sprinkler irrigation for other crops like sugarcane, groundnut and ragi. Water Use Efficiency method (Golam Rasul 2011, Ram Fishman, 2015) has the potential to reduce pumping approximately by 15 to $20 \%$ ( 150 to $200 \mathrm{mcm}$ annually). Cautious depressurization in aquifer unit III for safe mining of lignite along with periodic monitoring of hydraulic heads in all the four aquifer units around the lignite mine as well as near coast is required. Tube wells in aquifer unit IV can continue to tap drinking water supply to Chennai city ifthe reservoirs feeding Chennai city has poor storage. Also in an event of drought by monsoonal failure drinking water supply in the region can be met from aquifer unit IV.

Based on the guidelines recommended by National Green Tribunal(https://greentribunal.gov.in), declaring coastal zone as'Notified area' (from coast to $10 \mathrm{~km}$ inland) to regulate pumping wherein registration of existing groundwater abstraction structures, permission to operate wells for drinking and irrigation activity only and restrict new wells are few management strategies that can bring down groundwater withdrawal by $\sim 50$ mcm/year. In 2020, the National Green Tribunal (NGT) recommended that there must be no general permission for withdrawal of groundwater, particularly to any commercial entity, without an environment impact assessment of such activity and restricted groundwater extraction in over exploited areas for industries except for drinking water(http://cgwb.gov.in/CGWA/NGT-orders.html).Such permission should as per Water Management Plans to be prepared, based on mapping of individual assessment units. The plan strategy to limit pumping by 690 mcmy $^{-1}$ with optimum pumping of 1.85 $\mathrm{mcm} /$ day and pumping per well as $40 \mathrm{~m}^{3} /$ day in the coastal zone (maximum well depth $50 \mathrm{~m}$ bgl) and 80 to $120 \mathrm{~m}^{3} /$ day in the inland zone is the controllable hydrogeological environment to protect CCAS from sea water intrusion. Monitoring is inclusive part of AUMP; hence specially built piezometers fitted with telemetric automatic water level and water quality recorders would enhance monitoring mechanism.Finally, involving stakeholders mainly farmer's would sensitize people to achieve desirable results.

Table 5 Aquifer management strategies of Cuddalore coastal aquifer system.

\section{Conclusion}

Sustainability of the coastal groundwater resources has been a critical issue as pumping-induced hydraulic head draw down has the potential to reverse the hydraulic gradient into the coastal aquifer. The Aquifer Unit Management Plan (AUMP) is a groundwater resources management plan designed for Cuddalore coastal aquifer system to understand and manage its resources in a sustainable way. AUMP is decisive as it cogitates annual groundwater withdrawal limit, annual recharge, and hydraulic heads of the aquifer units, management strategies and administrative measures. With complex aquifer hydraulics and processes within, aquifer unit wise management interventions can guide water managers to initiate action plan and actswiftly to protect the coastal aquifer system from sea water intrusion.As many coastal aquifers in the sub-continent lack management plan citing its complexity, AUMP designed for Cuddalore aquifer coastal system can be broadly amended to single as well as multi-layered coastal aquifers of the sub-continent.

\section{Declarations}

\section{Availability of data and material}

There are no linked research data sets for this submission. The following reason is given: Data will be made available on request

\section{Competing interests}

No competing interests exists.

\section{Funding}

The entire study has been carried out as part of annual action plan of NAQUIM studies of the department and there is no funding.

\section{Authors' contributions}

Authors contribution both the authors have made equal contribution in the study and also in the preparation of the manuscript.

\section{Acknowledgements}

The authors thank the Chairman, Central Ground Water Board (CGWB), Regional Director, SECR, Chennai and all the officers/staffs of CGWB for their support. This paper contains the views of the authors and need not necessarily be the views of the department. 


\section{References}

1. Amrtha Kasturi Rangan, (2016) Participatory Groundwater Management: Lessons from Programmes Across India IIM kozhikode society \& management review, volume: 5 issue: 1, page(s): 8-15, https://doi.org/10.1177/2277975215617861

2. Anandan, K, Sahay, S, Karthikeyan, S (2010). Delineation of Recharge Area and Artificial Recharge Studies in the Neyveli Hydrogeological Basin. Mine Water and the Environment. 29. 14-22. 10.1007/s10230-009-0090-8.

3. Anandan KS, Sahay SN, Ramabadran TK, Shiv Prasad S (2010) Ground water control techniques for safe exploitation of the Neyveli lignite deposit, Cuddalore District, Tamil Nadu, India. Mine Water Environ. doi:10.1007/s10230-009-0089-1

4. Aristotelis Mantoglou, (2003) Pumping management of coastal aquifers using analytical models of saltwater intrusion, Water Resources Research,vol.39,no.12,1335,doi:10.1029/2002wr001891,2003

5. Barazzuoli, P., Nocchi, M., Rigati, R.Massimo Salleolini (2008). A conceptual and numerical model for groundwater management: a case study on a coastal aquifer in southern Tuscany, Italy. Hydrogeology J 16, 1557-1576. https://doi.org/10.1007/s10040-008-0324-z

6. Bear J (1999) Conceptual and mathematical modelling in sea water intrusion in coastal aquifers, Concepts, methods and practices, edited by J. Bear et al., pp.127-161, Kluwer Acad, Norwell, Mass.

7. Cendrero A, Fischer D W (1997) A procedure for assessing the environmental quality of coastal areas for planning and management. J. Coastal Res. 13(3), 732-744.

8. CGWB (2015) Pilot Project Report on Aquifer mapping in Lower Vellar watershed, Cuddalore district, Tamilnadu. https://cgwb.gov.in/AQM

9. CGWB (2017) Aquifer mapping and groundwater management of Chennai aquifer system, http://cgwb.gov.in/aqm/naquim_report/tamilnadu/chennai\%20aquifer\%20system.pdf

10. CGWB (2019a) Technical note on safe hydraulic heads and optimum pumping in Cuddalore coastal aquifer system based on numerical modelling by Gnanasundar D and Senthilkumar M. Technical report, Central Ground Water Board, Chennai.

11. CGWB(2019b) Groundwater year book of Tamilnadu and UT of Puducherry - 20182019http://cgwb.gov.in/Regions/SECR/Reports/GWYEARBOOK\%202018-19_tamil\%20nadu.pdf.

12. CGWB (2020) Groundwater data access, groundwater data download, Tamilnadu, Cuddalore District http://cgwb.gov.in/GW-data-access.html

13. Costall, A.R., Harris, B.D., Teo, B. (2020). Groundwater Throughflow and Seawater Intrusion in High Quality Coastal Aquifers. Sci Rep $10,9866$. https://doi.org/10.1038/s41598-020-66516-6

14. Elayarajaa M., D. Kumarasamy (2019) Charcoalified Wood of Hopeniumpondicherriensis(Dipterocarpaceae) from Neyveli Lignite Formation International Letters of Natural Sciences, ISSN: 2300-9675, Vol. 75, pp 36-40 Revised: 2019-03-19 doi:10.18052/www.scipress.com/ILNS.75.36

15. Gnanasundar D and Elango L (2000) Groundwater Flow Modeling of a Coastal Aquifer near Chennai City, India. Journal of Indian Water Resources Society, 20, 162-164.

16. Golam Rasul 2011 The role of the Himalayan mountain systems in food security and agricultural sustainability in south Asia, International Journal of Rural management, 6(1), 2010: 95-116

17. https://doi.org/10.1177/097300521100600105

18. Holland P.G. (1998) Saltwater wedge. In: Hydrology and Lakes. Encyclopedia of Earth Science. Springer, Dordrecht, DOI: https://doi.org/10.1007/1-4020-4513-1_195

19. Hoori Ajami(2020) Encyclopaedia of Geology, https://doi.org/10.1016/B978-0-12-409548-9.12388-7

20. Kandasamy, Selvaraj, Sooriamuthu, Ramasamy. (1998). Depositional environment of Cuddalore Sandstone Formation, Tamil Nadu. Journal of the Geological Society of India. 51. 803-812.

21. Kocha M., P. Arlaib, A. Lukjanb (2012) Modeling Investigation on the future Permissible Yield in upper Chiang Rai Aquifers System, Procedia Engineering 32 (2012) p 69-76

22. Marykutty Abraham and Mohan S (2019) Effectiveness Of Check Dam And Percolation Pond With Percolation Wells For Artificial Groundwater Recharge Using Groundwater Models, Water Supply 19 (7): 2107-2115.https://doi.org/10.2166/ws.2019.091

23. Mandaokar B D, Debi Mukherjee (2014)Palynostratigraphy Of The Cuddalore Formation (Early Miocene) Of Panruti, Tamil Nadu, India, Journal of Paleontological society of India. Volume 59 (1), p. 69-80.

24. Memoirs of the Geological Survey of India (1969) Geology and groundwater aspects of the Neyveli Lignite Field vol 94 p-29818.

25. Nagendra R and Nallapa Reddy A (2017) Major Geologic Events Of The Cauvery Basin, India And Their Correlation With Global Signatures - A Review, Journal of Palaeogeography, Volume 6, Issue 1, January 2017, Pages 69-83

26. Paul H Jones, V Subramanyam (1961) Ground-Water Control in the Neyveli Lignite Field, South Arcot District, Madras State, India, Economic Geology Vol. 56, 1961, p. 273-298.

27. Ram Fishman, NareshDevineni and Swaminathan Raman, 2015. Can improved agricultural water use efficiency save India's groundwater? Environ. Res. Lett. 10 (2015) 084022 
28. Rangarajan, R. Muralidharan, Devanatha, Deshmukh, S. \&Hodlur, G, Rao, T.. (2005). Redemarcation of recharge area of stressed confined aquifers of Neyveli groundwater basin, India, through tritium tracer studies. Environmental Geology. 48. 37-48. 10.1007/s00254-005-1254-x.

29. Ravi KumarV, S. N. Sahay, N. Periasamy, S. Shiv Prasad S, Karthikeyan (2010) Ground Water Basin Management at the Neyveli Lignite Mines, Mine and water environment 20(1), P 23-28

30. ReichardE,JohnsonT(2005)Assessment of Regional Management Strategies for Controlling Seawater Intrusion. Journal of WaterResources Planning Management Vol. 131, p. 280-291

31. Senthilkumar, M. and Elango, L., (2004). Three-dimensional mathematical model to simulate groundwater flow in the lower Palar River basin, southern India. Hydrogeology Journal, 12(4): 197-208.

32. Senthilkumar M, GnanasundarD,Sampath Kumar (2017) Deciphering freshwater/saline water interface in and around northern Chennai Region, Southern India, Clean and sustainable groundwater in India, p.25 to 38.

33. Sherif, Mohsen, Singh, Vijay (1990) A note on saltwater intrusion in coastal aquifers. Water Resources Management. 4. $123-134$. 10.1007/BF00429801.

34. Siaka M, Dokou, Z, Karatzas G P (2017)Management of the saltwater intrusion phenomenon in the alluvialaquifer of Katapola, Amorgos, Greece. Water Sci. Technol. Water Supply.

35. Sudhir Yadav, Balwinder-Singh, Elizabeth Humphreys, Surinder SinghKukal(2012). Effective Management of Scarce Water Resources in NorthWest India. Agriculture sustainability, Progress and prospects in crop research, 2013 pp. 103-125. https://doi.org/10.1016/B978-0-12-4045606.00006-X

36. Subramanyam V (1969) Geology and ground water aspects of the Neyveli lignite field, South Arcot District, Madras State. Memoir of the Geological Survey of India, India, p 94

37. Twinkle D, G Srinivasa Rao, M Radhakrishna, and K S R Murthy (2016) Journal of Earth Syst. Sci. 125, No. 2, March 2016, pp. 329-342

38. Varma P. (2017) The System of Rice Intensification (SRI). In: Rice Productivity and Food Security in India. Springer, Singapore. https://doi.org/10.1007/978-981-10-3692-7_4

39. Woo-Dong Lee, Young-Jae Yoo, Yeon-Myeong Jeong and Dong-Soo Hur (2019) Experimental and Numerical Analysis on Hydraulic Characteristics of Coastal Aquifers with Seawall, Water, 11, 2343; doi:10.3390/w11112343

40. Woo-Dong Lee, Young-Jae Yoo, Yeon-Myeong Jeong and Dong-Soo Hur (2019) Experimental and Numerical Analysis on Hydraulic Characteristics of Coastal Aquifers with Seawall, Water, 11, 2343; doi:10.3390/w11112343

\section{Figures}

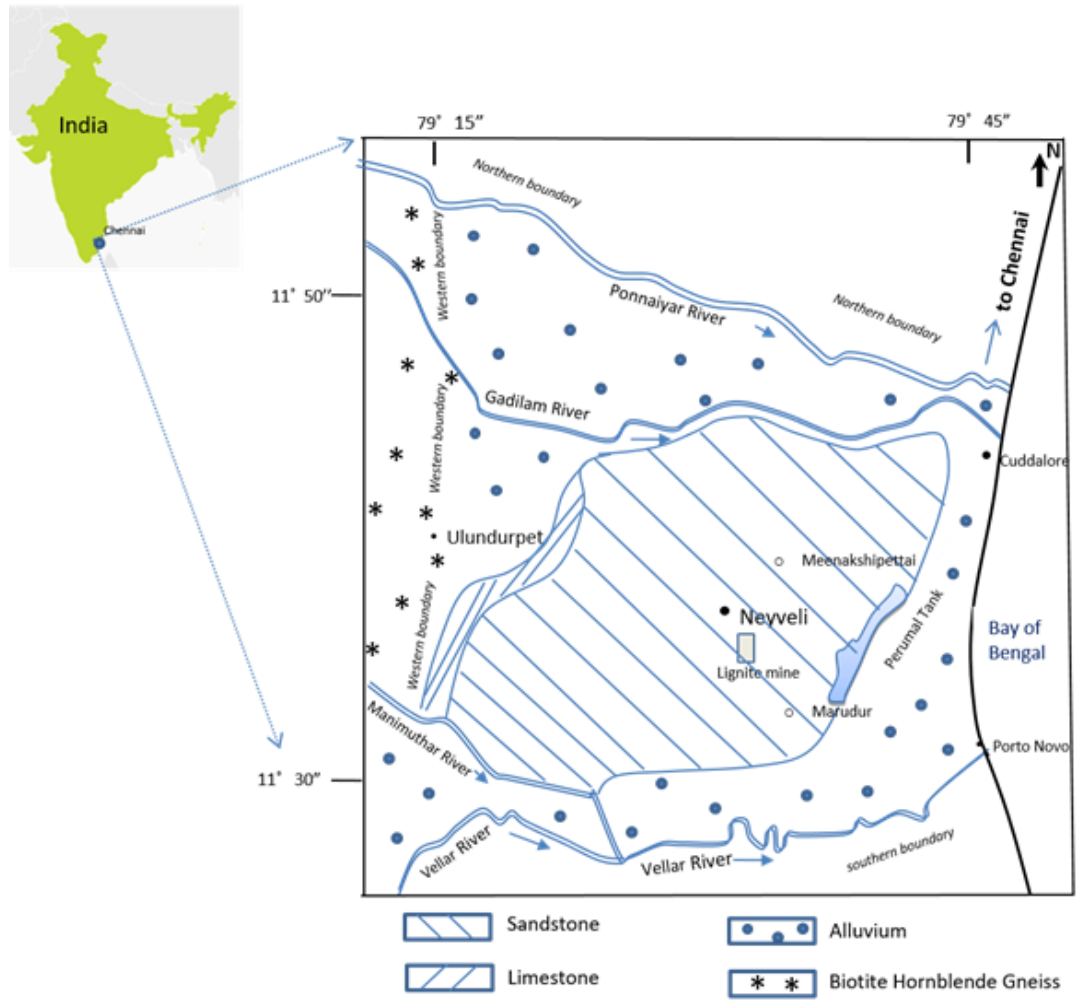

Page 12/14 
Figure 1

Map showing the location, boundary and regional geology of Cuddalore Coastal Aquifer System, India Location : Marudur village

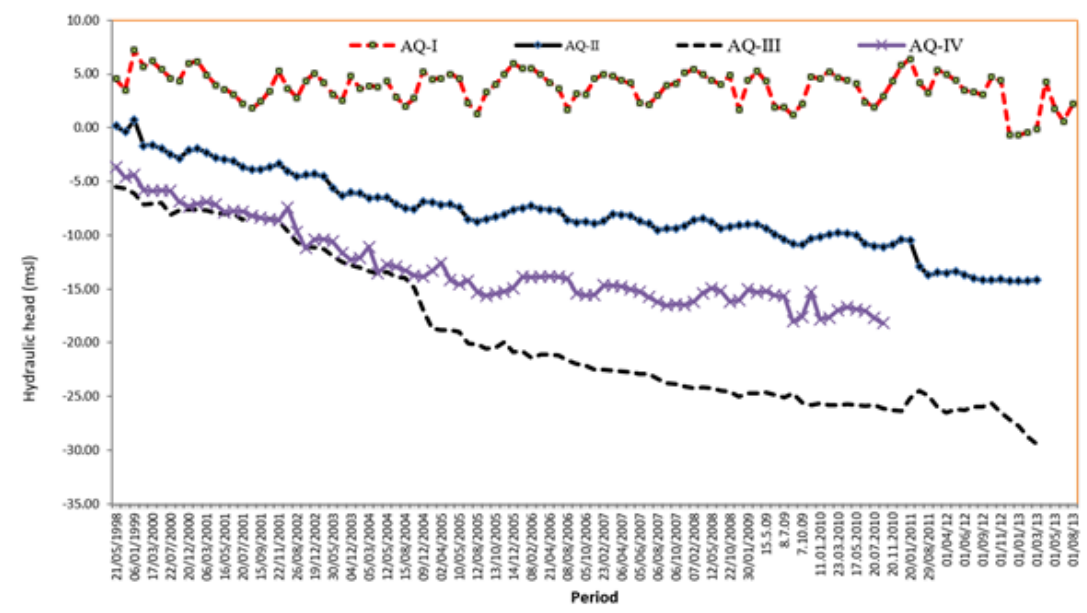

Explanation : AQ I Hydraulic head of aquifer unit I AQ-II Hydraulic head of aquifer unit II AQ-III Hydraulic head of aquifer unit III AQ-IV Hydraulic head of aquifer unit IV

\section{Figure 2}

Long term hydraulic head trends of aquifer units (1 to IV)

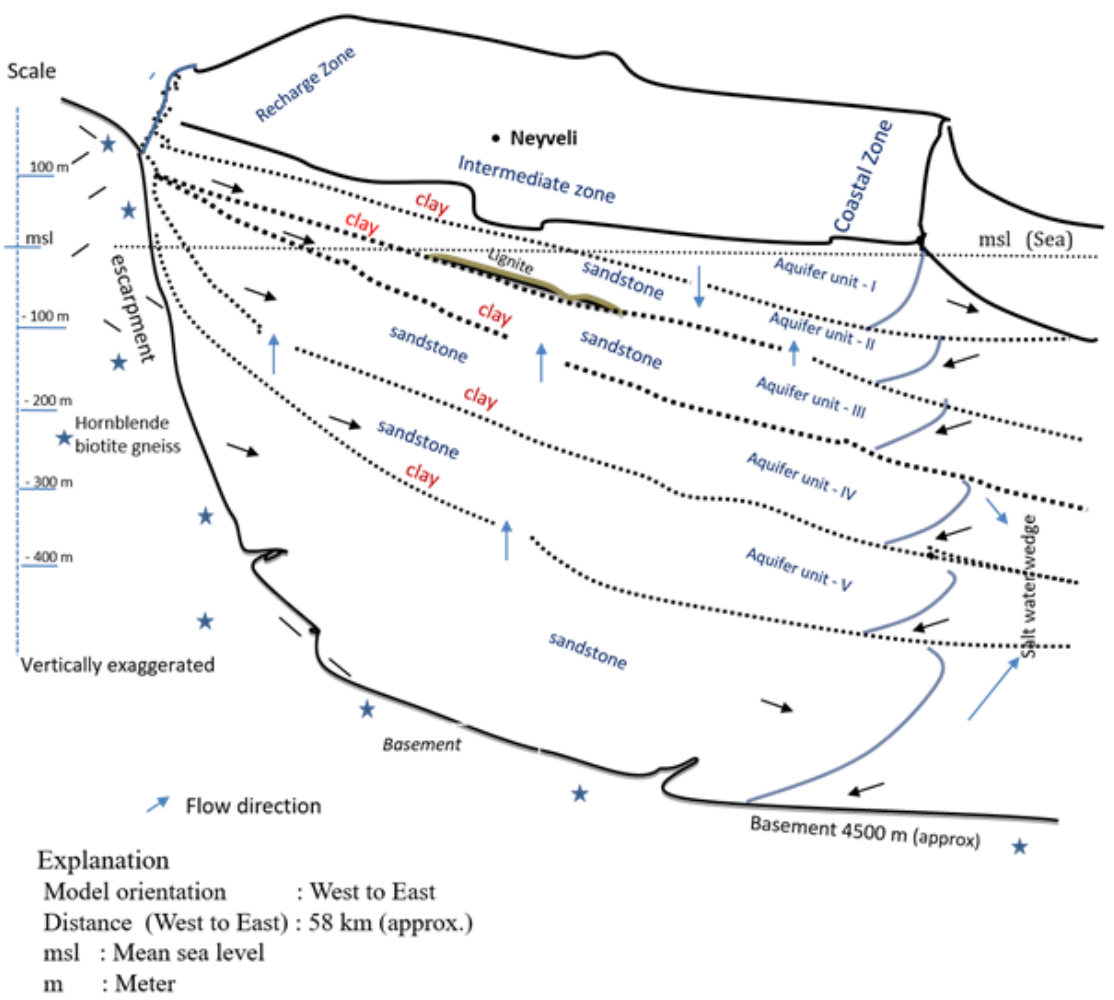

Figure 3

Conceptual model of Cuddalore coastal aquifer system, South India. 


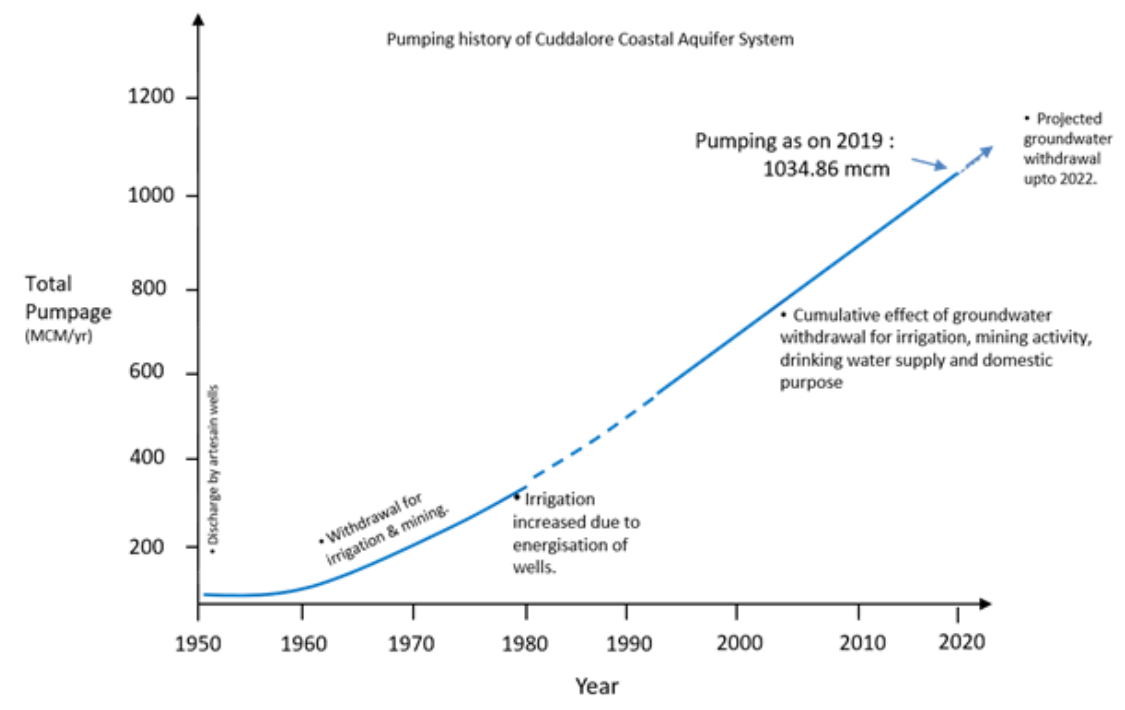

Figure 4

History of groundwater withdrawal from the cuddalore coastal aquifer system

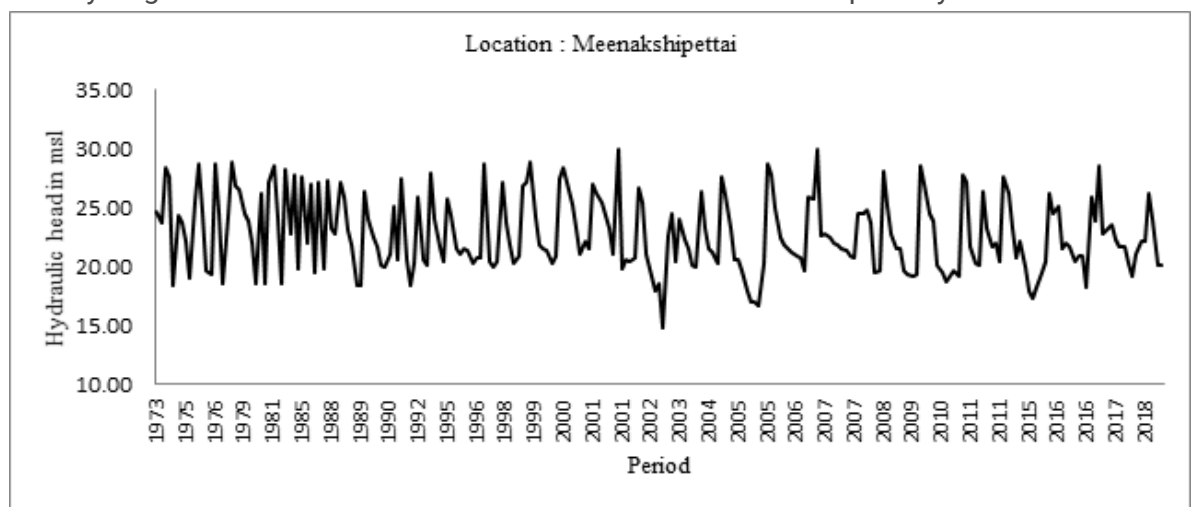

\section{Figure 5}

Long term (Period: 1973 - 2018) hydraulic head fluctuation and trend of aquifer unit I. 